\section{To: (Recelving Organization) \\ Distribution \\ 5. Proj./Prog./Dept./Div.: \\ RPP Corrosion Probe}

8. Originator Remarks:

This document satisfies the requirements of Milestone A.4-1 of FY

2000 TTP \# RLO-9-WT-41

11. Receiver Remarks:

11A. Design Baseline Document? $O$ Yes

Summary report of technical committee meeting

3. From: (Originating Organization)
Equipment Engineering
$\begin{aligned} & \text { 6. Design Authority/Design Agent/Geg. Engr:: } \\ & \text { EC Norman }\end{aligned}$

3. From: (Originating Organization)

Resp.

No

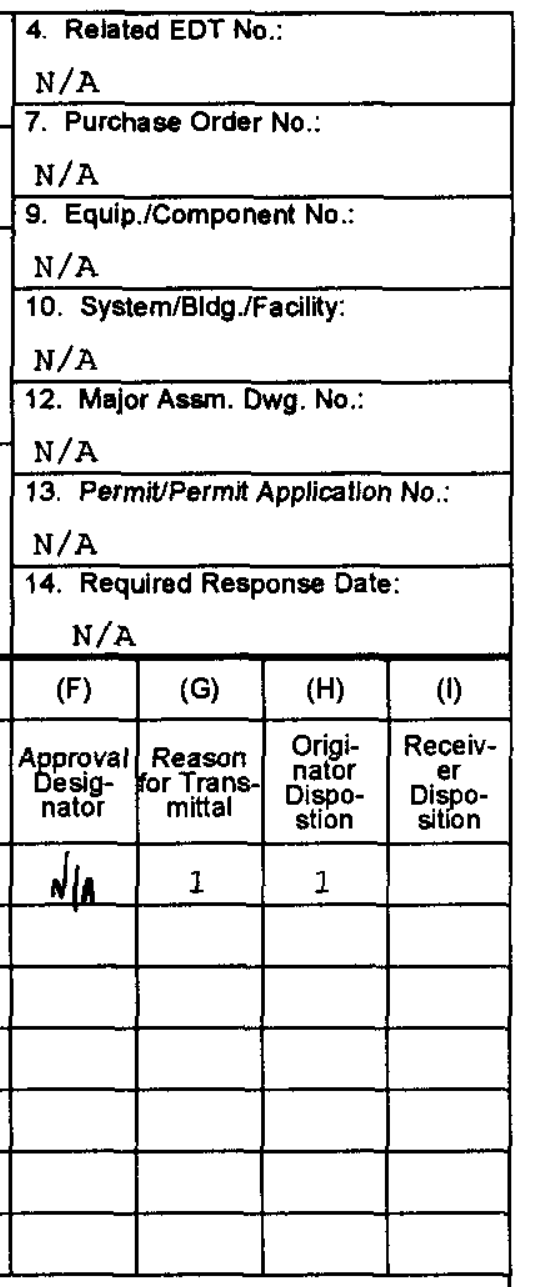

15.

\begin{tabular}{|l|l|}
\hline $\begin{array}{c}\text { (A) } \\
\text { Ifem } \\
\text { No. }\end{array}$ & (B) Document/Drawing No. \\
\hline 1 & RPP -6187 \\
\hline & \\
\hline & \\
\hline & \\
\hline & \\
\hline & \\
\hline
\end{tabular}

16.

\begin{tabular}{|c|l|}
\hline Approval Designator $(F)$ & \\
\hline E, S, Q D OR N/A & 1. Approval \\
$\begin{array}{c}\text { (See WHC-CM-3-5, } \\
\text { Sec. 12.7) }\end{array}$ & $\begin{array}{l}\text { 2. Release } \\
\text { 3. Information }\end{array}$ \\
\hline
\end{tabular}

17.

\begin{tabular}{|c|c|c|c|}
\hline $\begin{array}{l}\text { (G) } \\
\text { Rea- } \\
\text { son }\end{array}$ & $\begin{array}{l}\text { (H) } \\
\text { Disp. }\end{array}$ & (K) Signature & 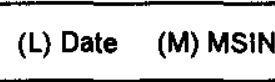 \\
\hline & & Design Authority & \\
\hline & & Design Agent & \\
\hline 1 & 1 & Loffét.ing. EC Norman E.C. & $\operatorname{man}<127100$ \\
\hline 1 & 1 & Cog.Mgr. AH Friber & D for $7 / 10 / 0$ \\
\hline & & QA & \\
\hline & & Safety & \\
\hline & & Env. & \\
\hline
\end{tabular}

18.

EChomm Signature of EDT Originator
KEY

DATA TRANSMITTED

(C) Sheet (D) Rev.

\begin{tabular}{|l|l|}
\hline & 0 \\
\hline & \\
\hline & \\
\hline & \\
\hline & \\
\hline
\end{tabular}

Reason for Transmittal (G)

4. Review

5. Post-Review

6. Dist. (Recelpt Acknow. Required)
(E) Titie or Description of Data Transmitted FY 2000 Tanks Focus Area Corrosion Monitoring Technical Committee Meeting Summary Report
Disposition (H) \& (I)

\begin{tabular}{|ll}
\multicolumn{2}{|c}{ Disposition (H) \& (I) } \\
$\begin{array}{ll}\text { 1. Approved } & \text { 4. Reviewed no/comment } \\
\text { 2. Approved w/comment } & \text { 5. Reviewed w/comment } \\
\text { 3. Disapproved w/comment } & \text { 6. Receipt acknowledged }\end{array}$ \\
\hline
\end{tabular}

wed w/comment

6. Receipt acknowledged SIGNATURE/DISTRIBUTION

SIGNATURE/DISTRIBUTION
(See Approval Designator for required signatures)

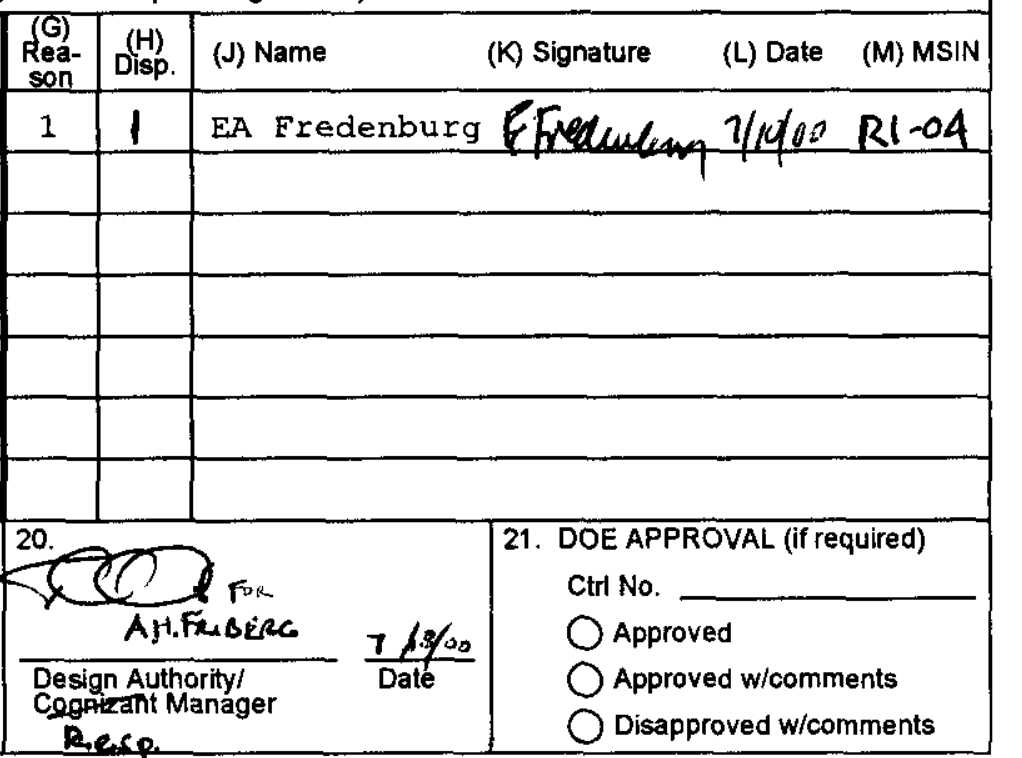




\title{
FY 2000 Tanks Focus Area Corrosion Monitoring Technical Committee Meeting Summary Report
}

\author{
E. C. Norman \\ CH2M HILL Hanford Group, Inc. \\ Richland, WA 99352 \\ U.S. Department of Energy Contract DE-AC06-96RL13200

$\begin{array}{ccl}\text { EDT/ECN: } & 629682 & \text { UC: } 2030 \\ \text { Org Code: } & 74700 & \text { Charge Code: } 112671 \\ \text { B\&R Code: } & \text { EW4010000 } & \text { Total Pages: } 2322 \\ & & \end{array}$

Key Words: corrosion monitoring, electrochemical noise, probe, Raman Spectroscopy

Abstract: Summary report of technical committee meeting

I'his document meets the requirements of TTP-RLO9-WT-4I Milestone A.4-1

TRADEMARK DISCLAIMER. Reference herein to any specific commercial product, process, or service by trade name, trademark, manufacturer, or otherwise, does not necessarily constitute or imply its endorsement, recommendation, or favoring by the United States Government or any agency thereof or its contractors or subcontractors.

Printed in the United States of America. To obtain copies of this document, contact: Document Control Services, P.O. Box 950, Mailstop H6-08, Richland WA 99352, Phone (509) 372-2420; Fax (509) 376-4989.
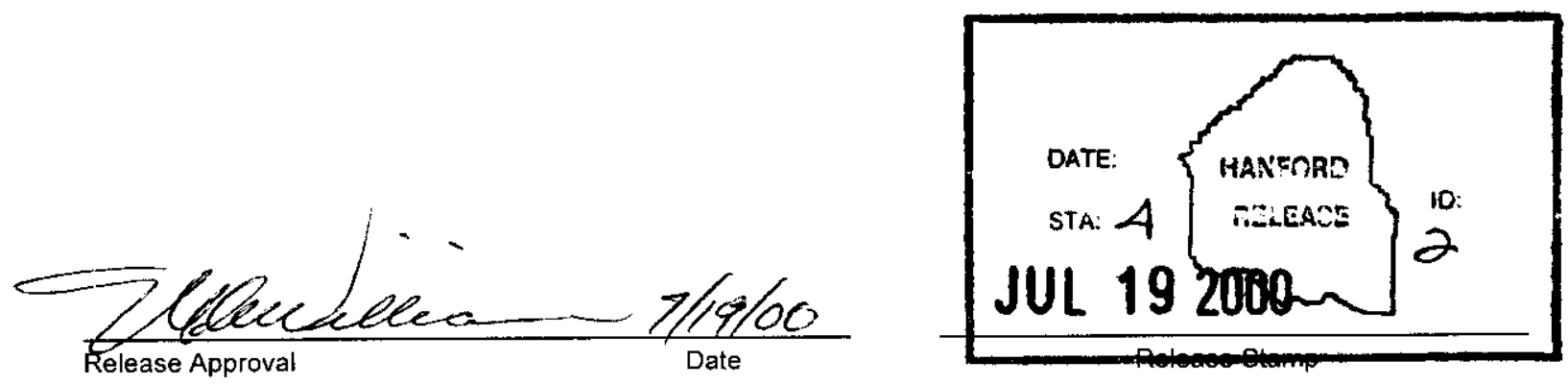

\section{Approved For Public Release}


RPP-6187, Rev. 0

FY 2000 Tanks Focus Area Corrosion Monitoring Technical Committee Meeting Summary Report

\section{G. L. Edgemon}

Hiline Engineering and Fabrication, Inc.

2105 Aviator Drive

Richland, Washington 99352 


\section{Introduction}

An information exchange on corrosion monitoring was held on March 28, 2000 as required by Milestone A.4-1 of TTP RL0-9-WT-41. The goal of the meeting was to communicate the status of the corrosion monitoring efforts at the Hanford Site, Savannah River Site, and at Oak Ridge National Laboratory. The meeting was attended by Mr. Glenn Edgemon from Hiline Engineering and Fabrication, Mr. Michael Harper from Oak Ridge National Laboratory (ORNL), and Dr. Graham Bell from M. J. Schiff and Associates. Dr. John Mickalonis from the Savannah River Site was unable to attend but sent a set of overview slides which were presented by Mr. Glenn Edgemon. A summary of topics discussed and products of the meeting are shown in this report. The agenda and hard copies of presentation materials are shown in the Attachment.

\section{Meeting Summary}

The meeting was called to order at 5:00 p.m. on March 28, 2000 by Glenn Edgemon. Mr. Edgemon presented the overview slides provided by Dr. Mickalonis on the status of the SRTC (Savannah River Technology Center) effort to design, fabricate and install a combined corrosion monitoring and chemistry monitoring system into a waste tank at the Savannah River Site (SRS). Dr. Mickalonis serves as the Principle Investigator for the corrosion monitoring portion of the probe and Dr. David Hobbs serves as Principle Investigator for the chemistry species monitoring portion of the probe.

The objective of the task is to install this system into SRS Tank 43. The two technologies (chemistry monitoring and corrosion monitoring) have been combined into one in-tank system due to tank space limitations. The system designer is EIC Laboratories. An initial design review was held in December 1998. Fabrication of the system is underway. Cold testing is expected to start within the next few months. Installation of the final system is expected in FY 2001. A weekly conference call between all concerned parties helps keep communications in order for this complex project.

Raman spectroscopy has been selected for the chemistry species monitoring portion of the probe. Electrochemical Noise $(\mathrm{EN})$ has been selected for the corrosion monitoring portion of the probe. Currently, mockup testing of both systems is underway. Probe head fabrication was completed in March 2000. Probe head is now at EIC laboratories where it will be fitted and assembled with the Raman instrumentation and corrosion monitoring cabling. The design of the lifting/drive mechanism for the probe head is near completion with fabrication expected to start within a few months. Bids are currently being taken by the Savannah River Site for the design and fabrication of the control panels that will be used to operate the lifting/drive mechanism, the Raman instrumentation and the corrosion monitoring equipment. Final test plans and training schedules for this system are currently being developed. 
The second presentation was made by Mr. Glenn Edgemon on the status of the multifunction corrosion probe that was deployed into tank 241-AN-105 on the Hanford Site on January 13, 2000. Mr. Edgemon serves as the technical point of contact for the current corrosion monitoring effort at Hanford. Dr. Edgar Norman serves as the Hanford site PI for this effort and as the site point of contact for corrosion monitoring.

One of the principle objectives of last year's TTP (TTP RL0-8-WT-21) at Hanford was to design, fabricate and install a multi-function corrosion probe into DST 241-AN-105 during FY 1999. Design work for the multi-function probe was completed in April 1999. The focus of the redesign effort was to improve upon the existing corrosion probe design and to add new capabilities to the in-tank probe. The redesign effort resulted in a multifunction instrument that contains several features not seen on previous Hanford corrosion monitoring systems. In addition to the eight channels of EN corrosion monitoring electrodes incorporated on previous probes, the new system is also fitted with an array of 22 thermocouples, a verification thermocouple, a tank waste high level detector, three ports for pressure/gas sampling and a set of strain gauges to monitor the effects of tank operations on the downhole instrumentation. These features add a great deal of functionality to the probe, provide for a better understanding of the relationship between corrosion and other tank operating parameters, and optimize the use of the riser that houses the probe. This system was installed in January 2000 and has been operating continuously since installation.

Several data quality issues were identified after the first few weeks of operation. These problems stemmed from the type of cable used between the corrosion monitoring instrumentation and the top of the in-tank probe. Specifically, the driven shields provided by the instrumentation were creating cross-talk between channels in Belden 8178 cable. Shields were recently modified to correct this problem. The system is operating normally now. Data from the system is posted periodically on the internet at http://www.hanford.gov/twrs/corrosion/data.htm.

The third presentation was made by Mr. Mike Harper from Bechtel Jacobs at Oak Ridge National Laboratory. Mr. Harper updated the group on the status of the Oak Ridge National Laboratory corrosion monitoring effort. The goal of the program is to adapt the Hanford type electrochemical noise based corrosion monitoring system to the $304 \mathrm{~L}$ stainless steel waste tanks at ORNL. Funding for the work comes from the TFA. Bechtel Jacobs Co. LLC is the EM M\&I contractor. Hiline Engineering and Fabrication is responsible for system design and fabrication. ORNL is responsible for facilities and buildings. Waste Management Federal Services is in charge of system operations.

The tank selected for system deployment is tank W-23, a 50,000 gallon low-level radioactive waste tank used primarily for storage of evaporator concentrate. The tank was installed in the mid-1970's in an underground stainless lined concrete vault. The tank is approximately 12 feet in diameter by 61.5 feet long. Sludges were removed in 1999 during a tank cleaning campaign. Waste is generally caustic with $\mathrm{pH}$ maintained at approximately 12.5 . Major anions are nitrates, nitrites, and sulfates. 
Corrosion monitoring system design, equipment selection, equipment checkout, and laboratory baseline testing in simulated wastes is scheduled for FY 2000 and will be performed by Mr. Glenn Edgemon at ORNL. Finalized design and system fabrication is scheduled for FY 2001 at Hiline Engineering.

\section{Conclusions}

The primary purpose of the annual meeting between the corrosion monitoring personnel at the various DOE sites is to facilitate communications and promote technology transfer between the two sites. The close communications and good spirit of teamwork being exhibited between the parties representing the Hanford and Savannah River Sites has helped the Savannah River Site effort avoid many of the problems encountered during the initial development effort at Hanford. Similar benefits can be expected over the next few years as the ORNL program is developed.

Expected products of this meeting as defined in Milestone A.4-1 of TTP RL0-9-WT-41 are reports on the status of technical work at the sites, discussions of emerging technical issues, and results of laboratory experiments and field trials. The formal meeting, informal discussions throughout the week, and the presentation materials shown in the attachment to this document fulfill the expectations of this meeting.

At the conclusion of the meeting it was agreed that close communications should continue between the concerned parties at ORNL, SRTC and Hanford. Tentative plans were made to hold a similar meeting in approximately one year. 
RPP-6187, Rev. 0

Attachment A: Agenda and Presentation Materials from FY 2000 TFA Information Exchange 


\author{
CORROSION/2000 \\ TFA INFORMATION EXCHANGE \\ ELECTROCHEMICAL NOISE BASED CORROSION MONITORING \\ TUESDAY, MARCH 28, 2000 \\ IMMEDIATELY FOLLOWING T-2A COMMITTEE MEETING - SAME ROOM \\ SO...APPROXIMATELY FROM 5:00 PM - 7:00 PM \\ ORLANDO CONVENTION CENTER \\ ORLANDO, FLORIDA
}

\author{
Contact: Glenn Edgemon \\ e-mail: glenne@hilineeng.com \\ Phone: 509-943-9043
}

Fax: 509-943-0856

1.0 Call to order

2.0 Introduction of meeting attendees

3.0 New business

1 Information exchange: status of technical activities at SRS, Hanford, ORNL, and other DOE sites.

.2 Open discussion and questions from floor on new technology, successes, corrosion control issues, challenges, infuriations, etc.

4.0 Old business

5.0 Adjournment 


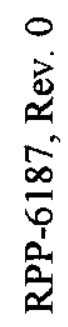
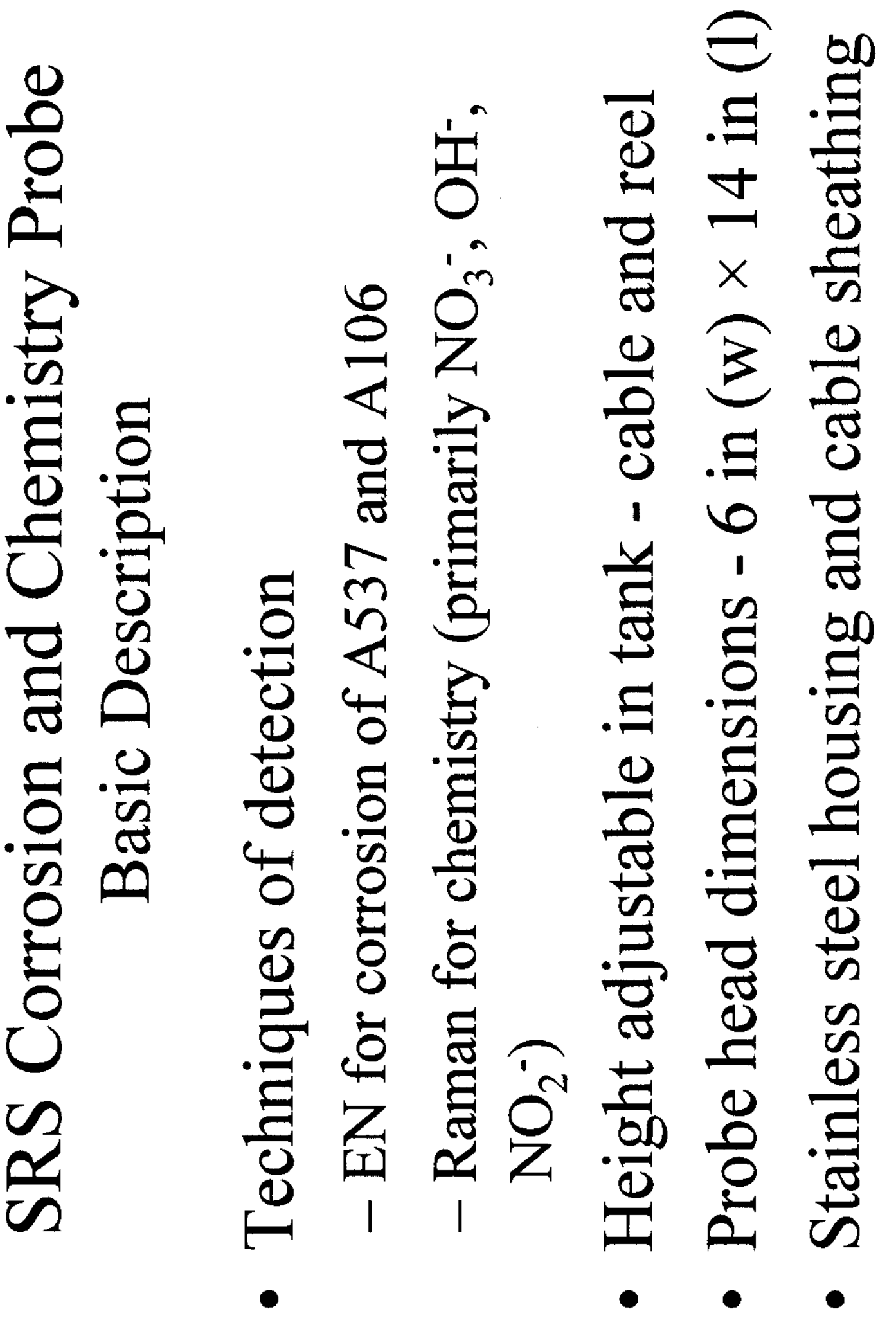
0
0
0
0
0
0
0
0
0

$\frac{0}{0}$

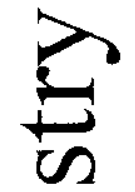

$\frac{E}{0} \cdot \frac{E}{0}$

$\because 0$

$\mathbb{0}$

$e_{0}^{\infty} \cdot \frac{0}{0}$

0

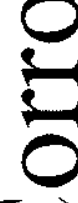

( )

(

$\Omega$

C2
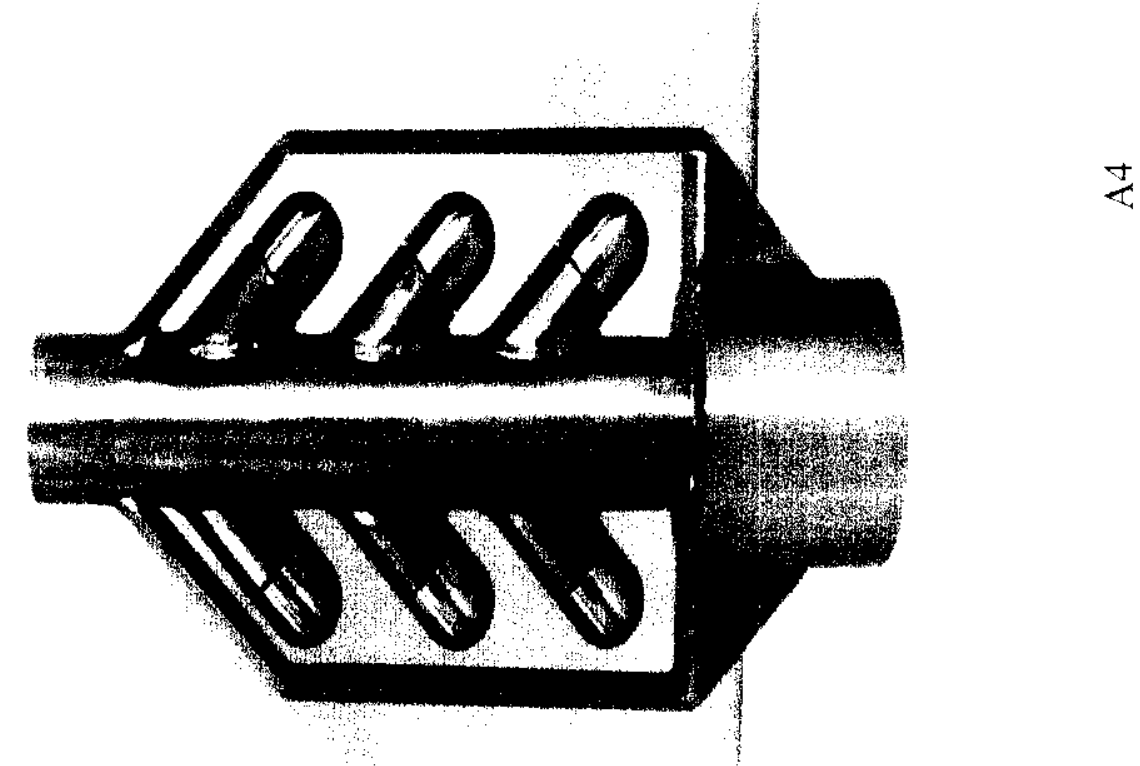
0
0
0
0
0
0
0
0
0

$\frac{0}{2}$

5

E)

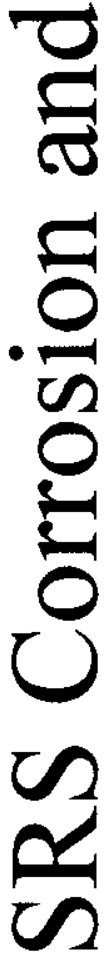

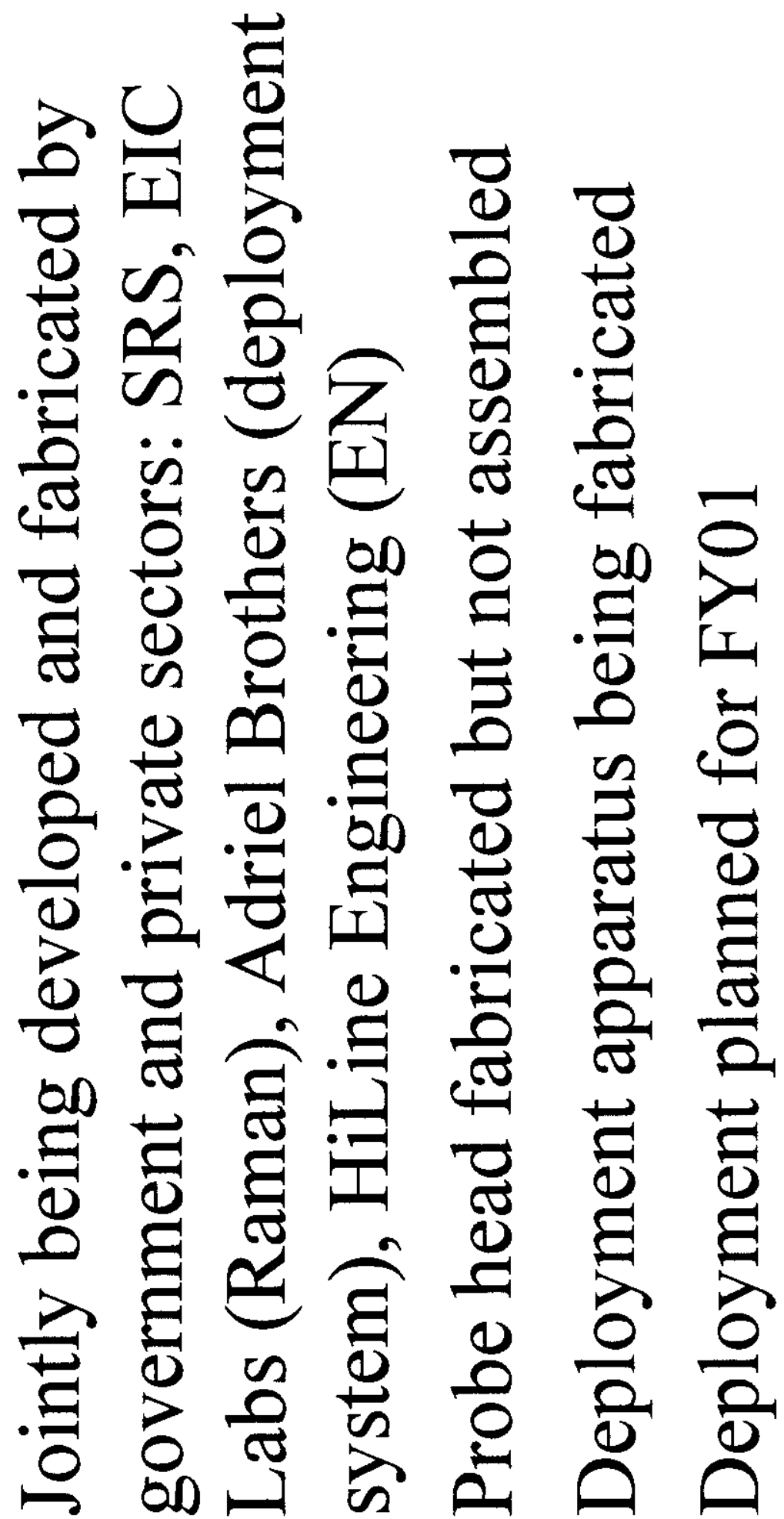

4 
0
0
0
0
0
0
0
0
0

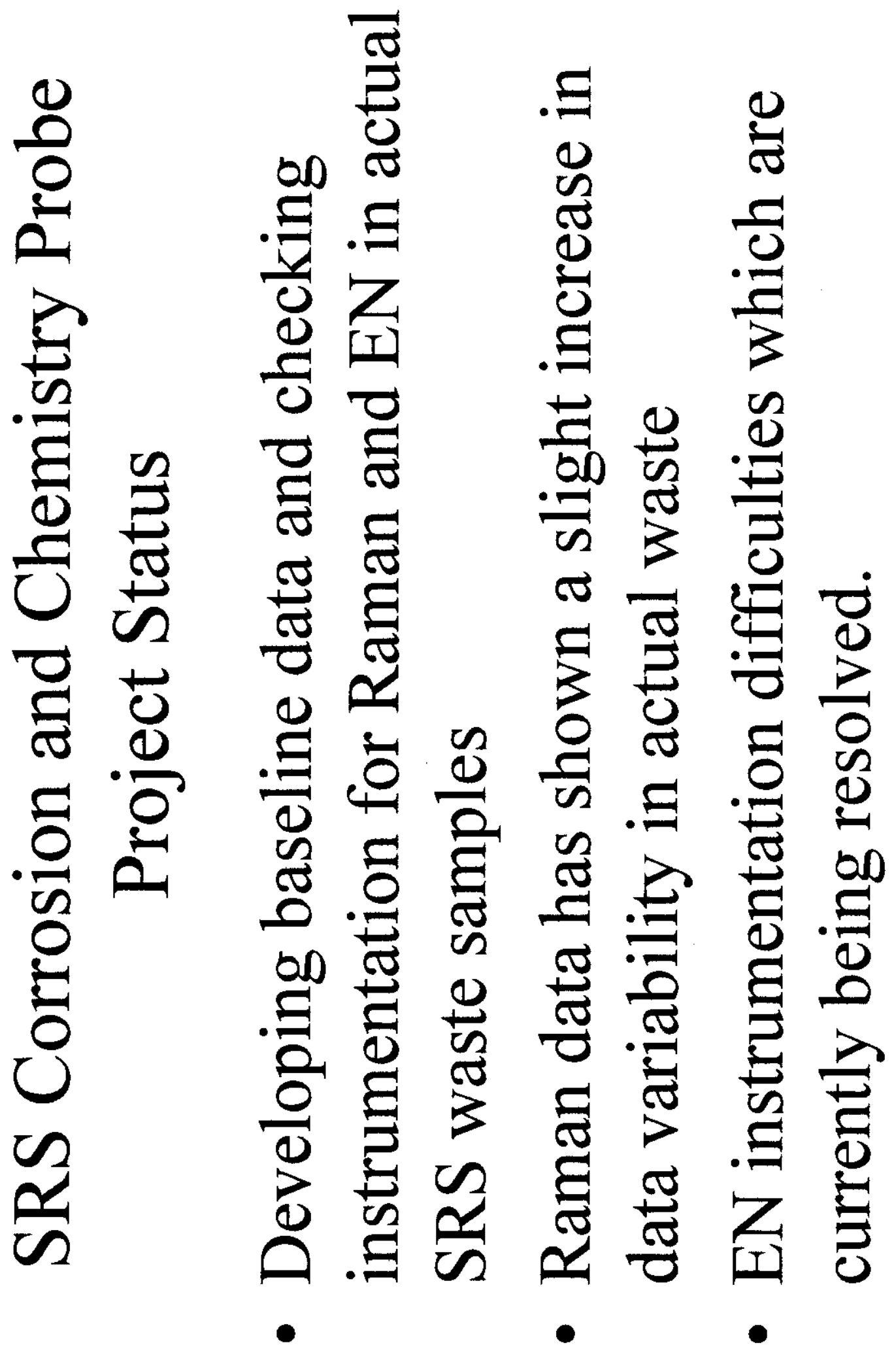




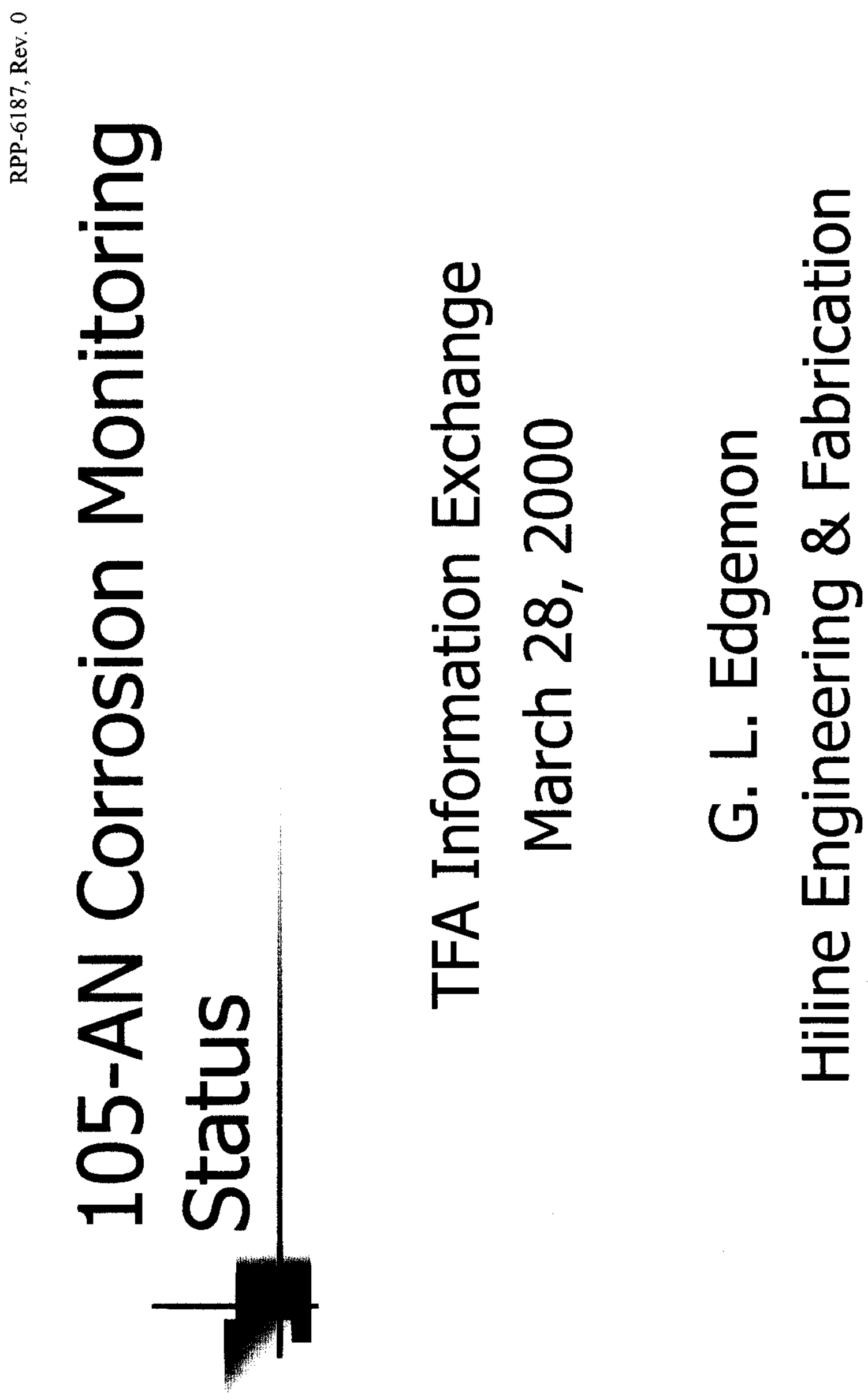




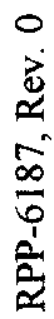

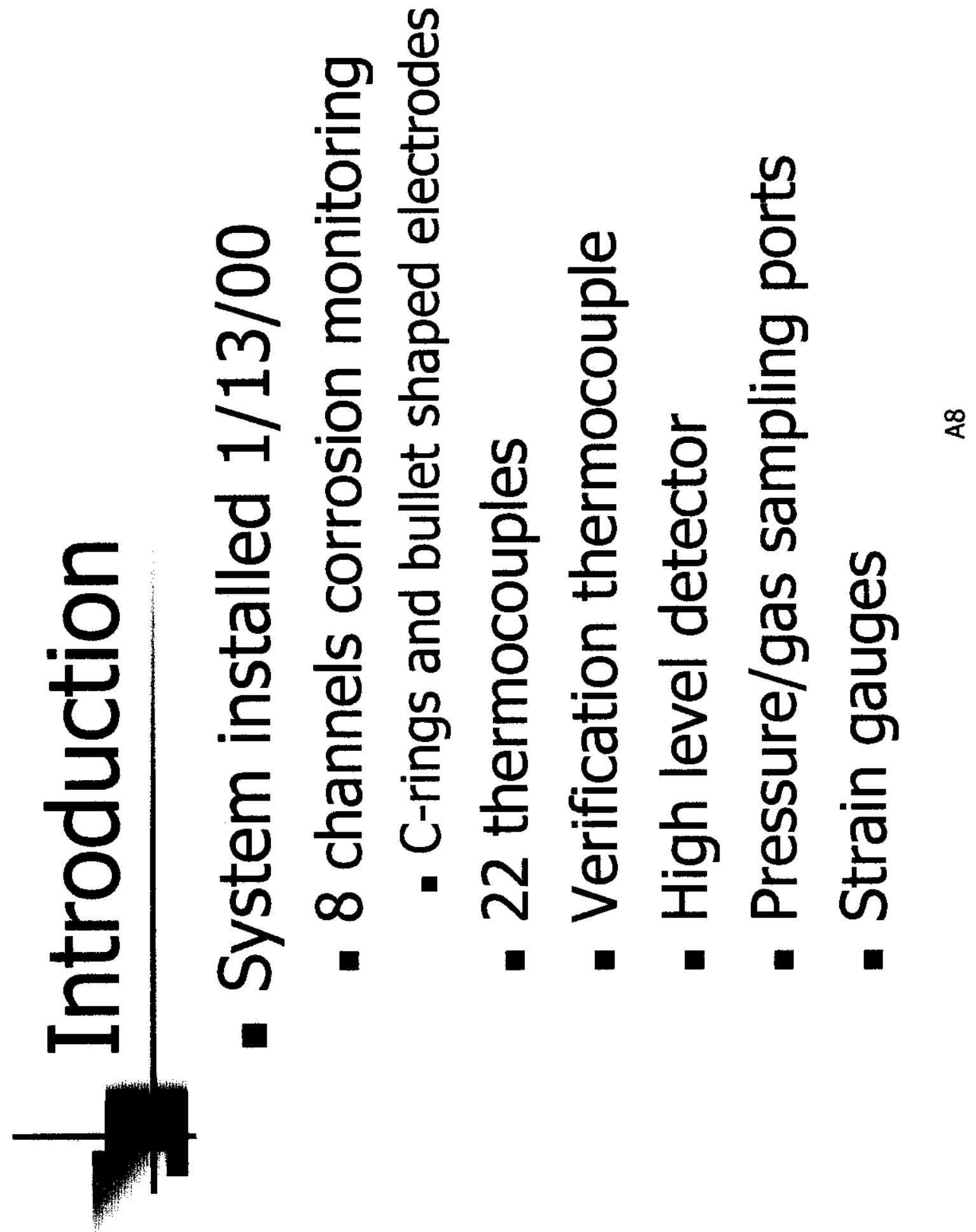




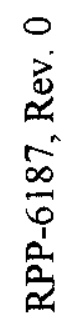

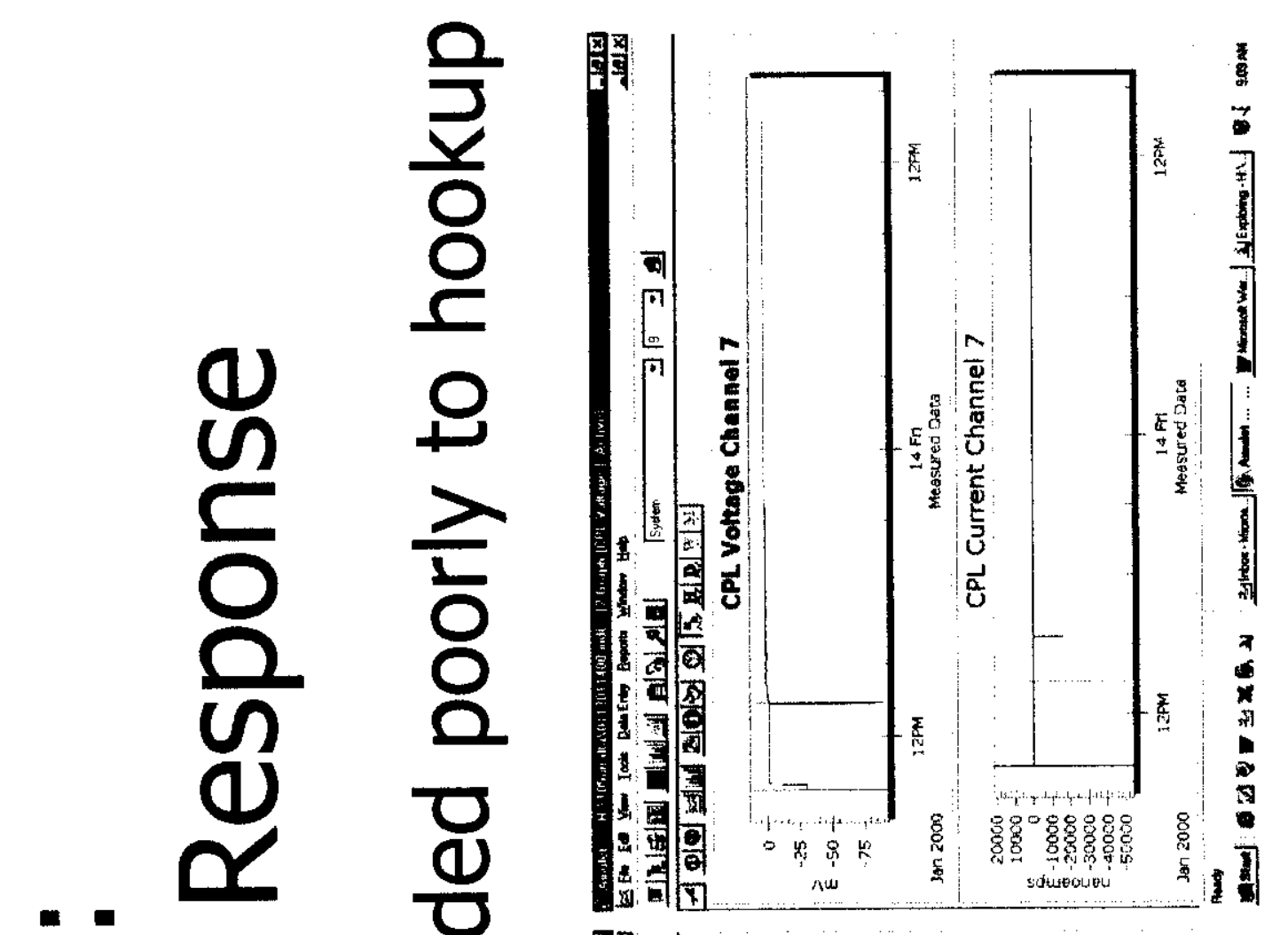

a
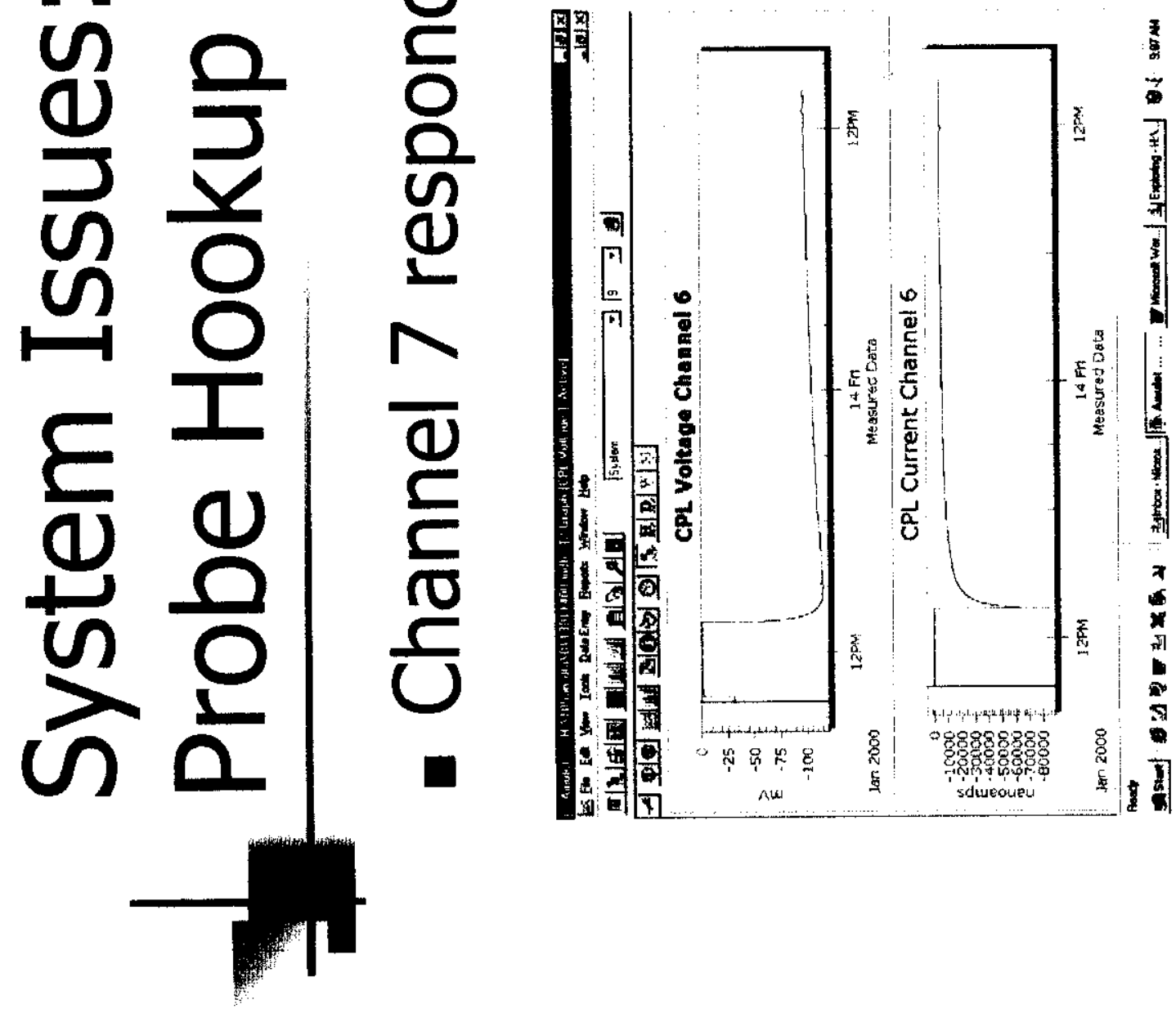


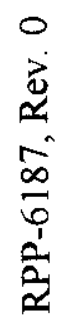
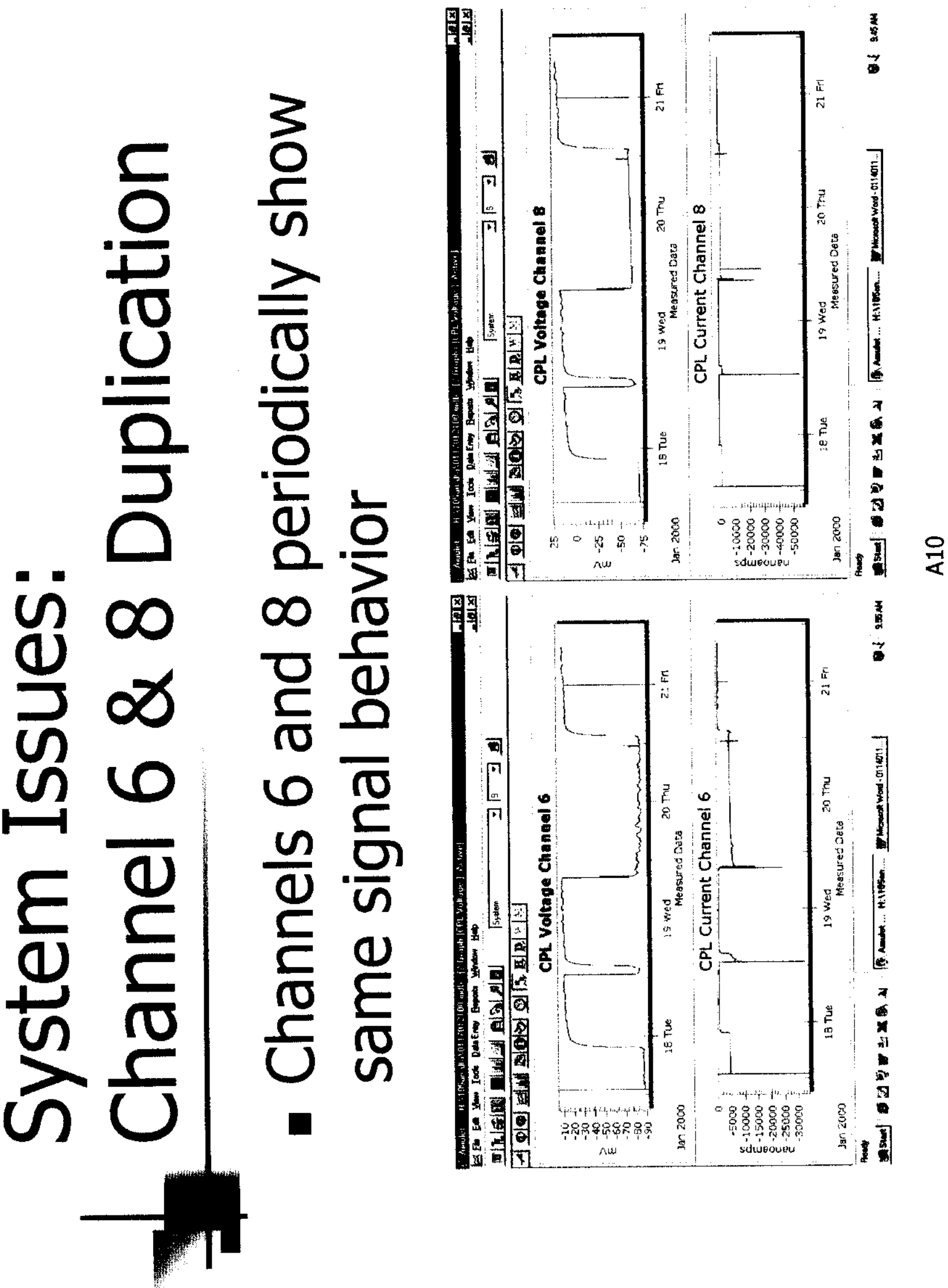
0
0
0
0
0
0
01
0
0
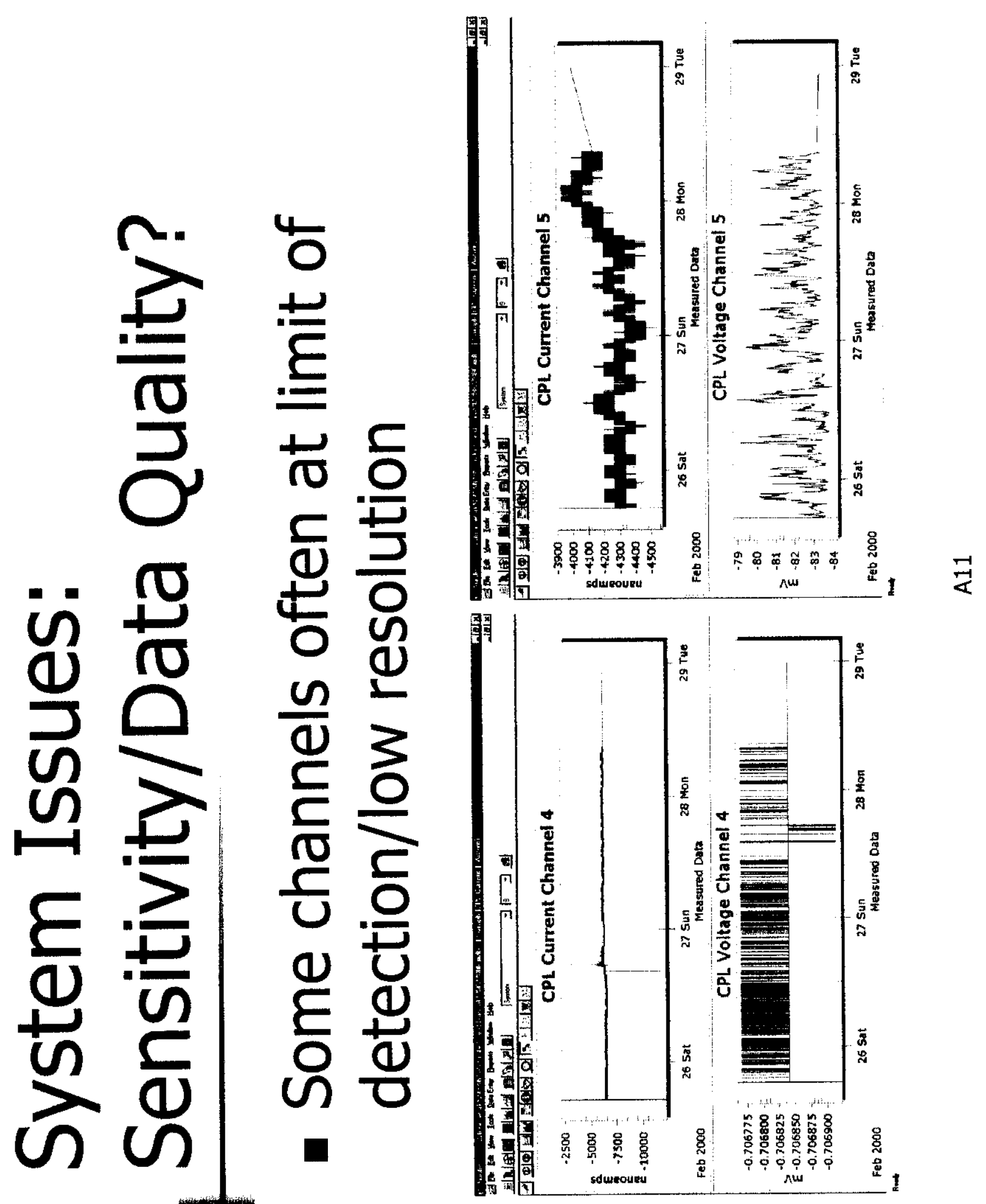
0
2
0
0
0
0
0
0
0
0

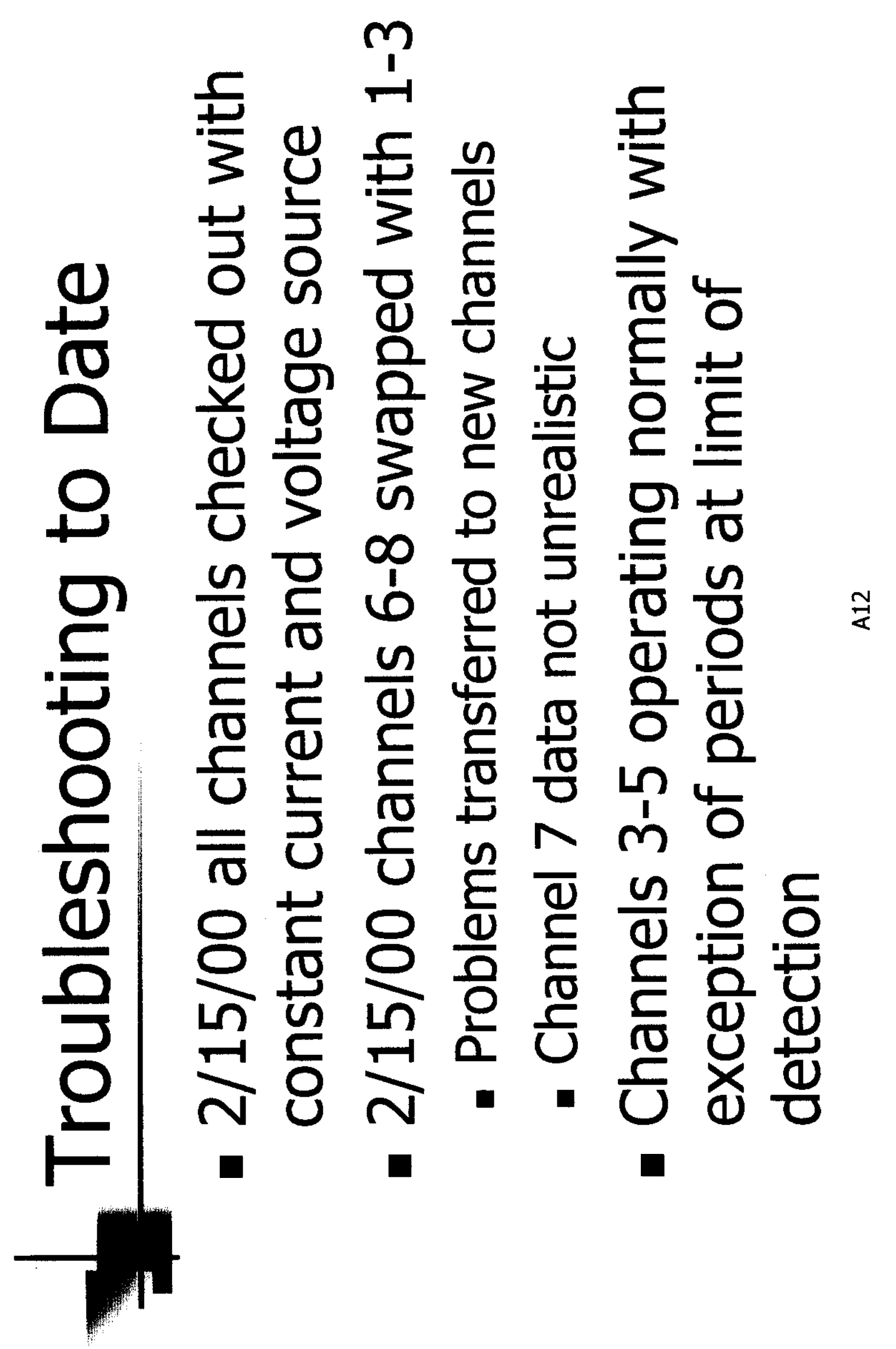


0
2
0
0
0
0
0
0
0

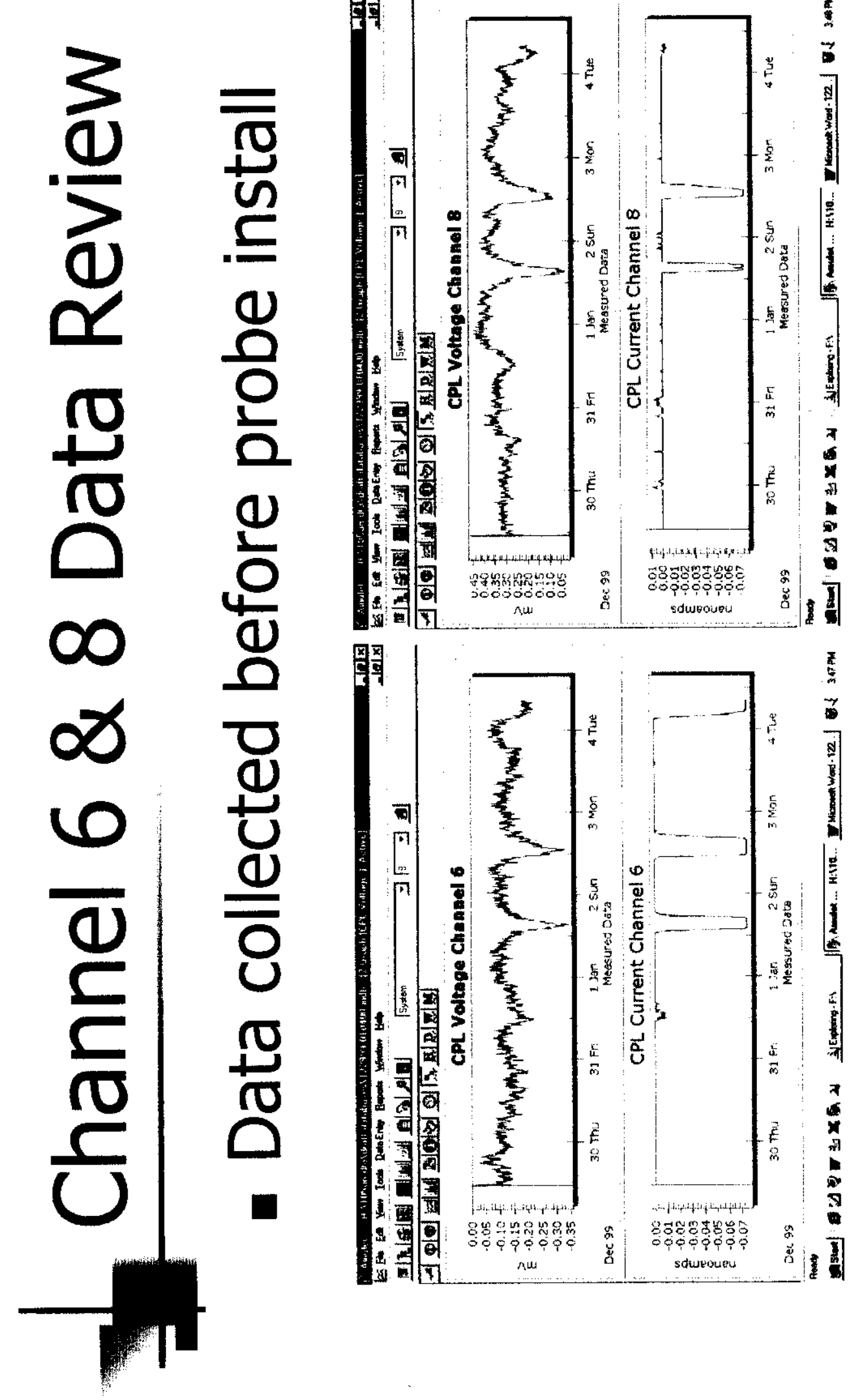

$\frac{m}{2}$ 


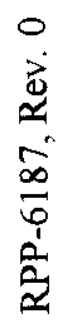
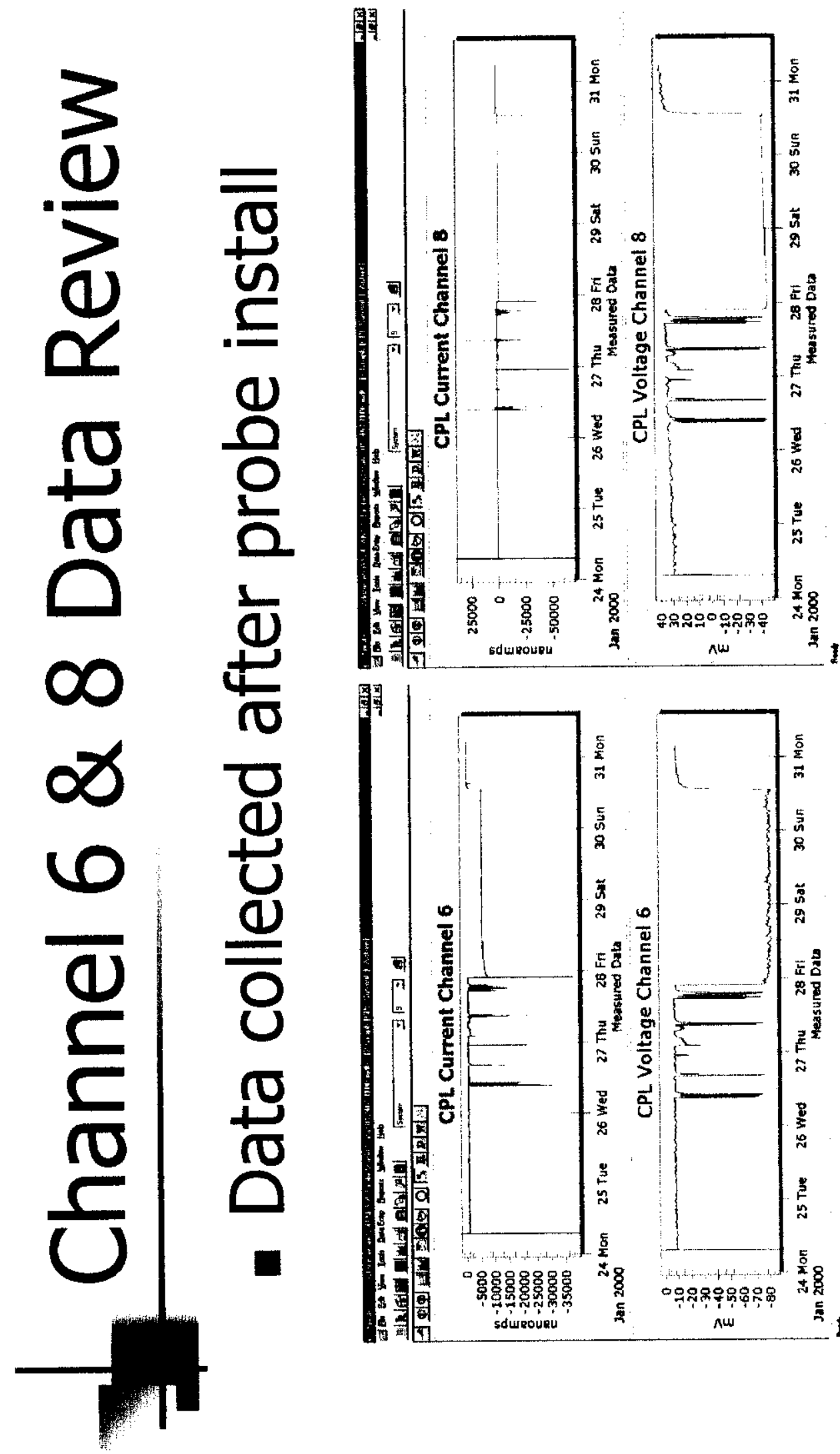

$\frac{5}{4}$

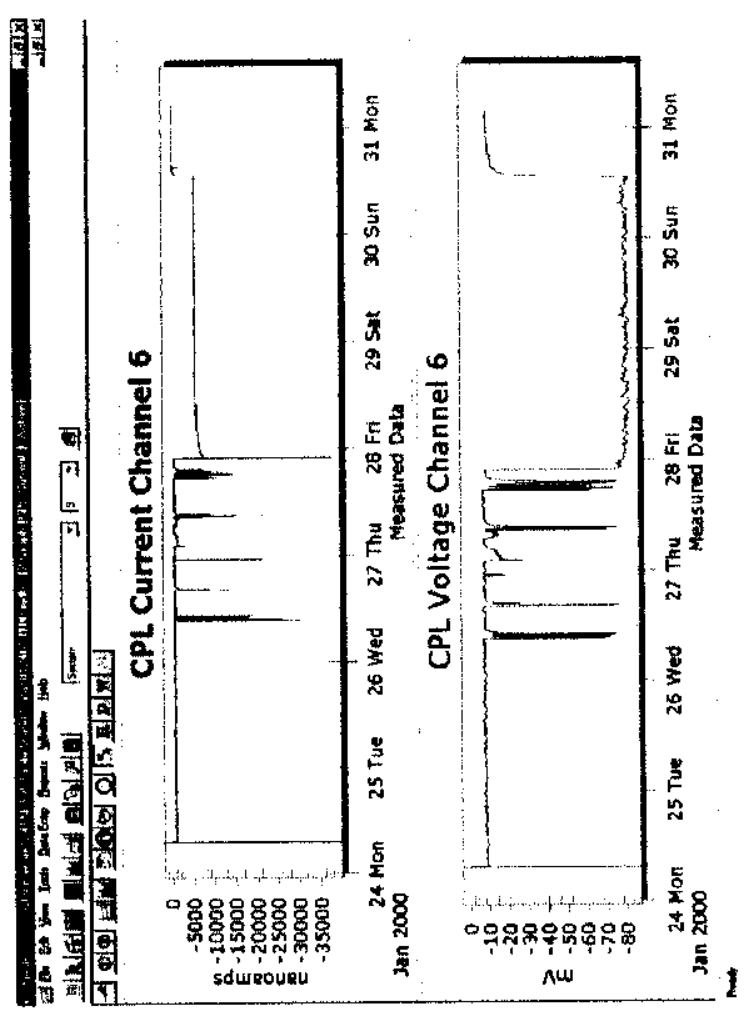




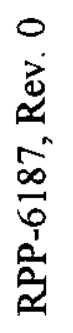

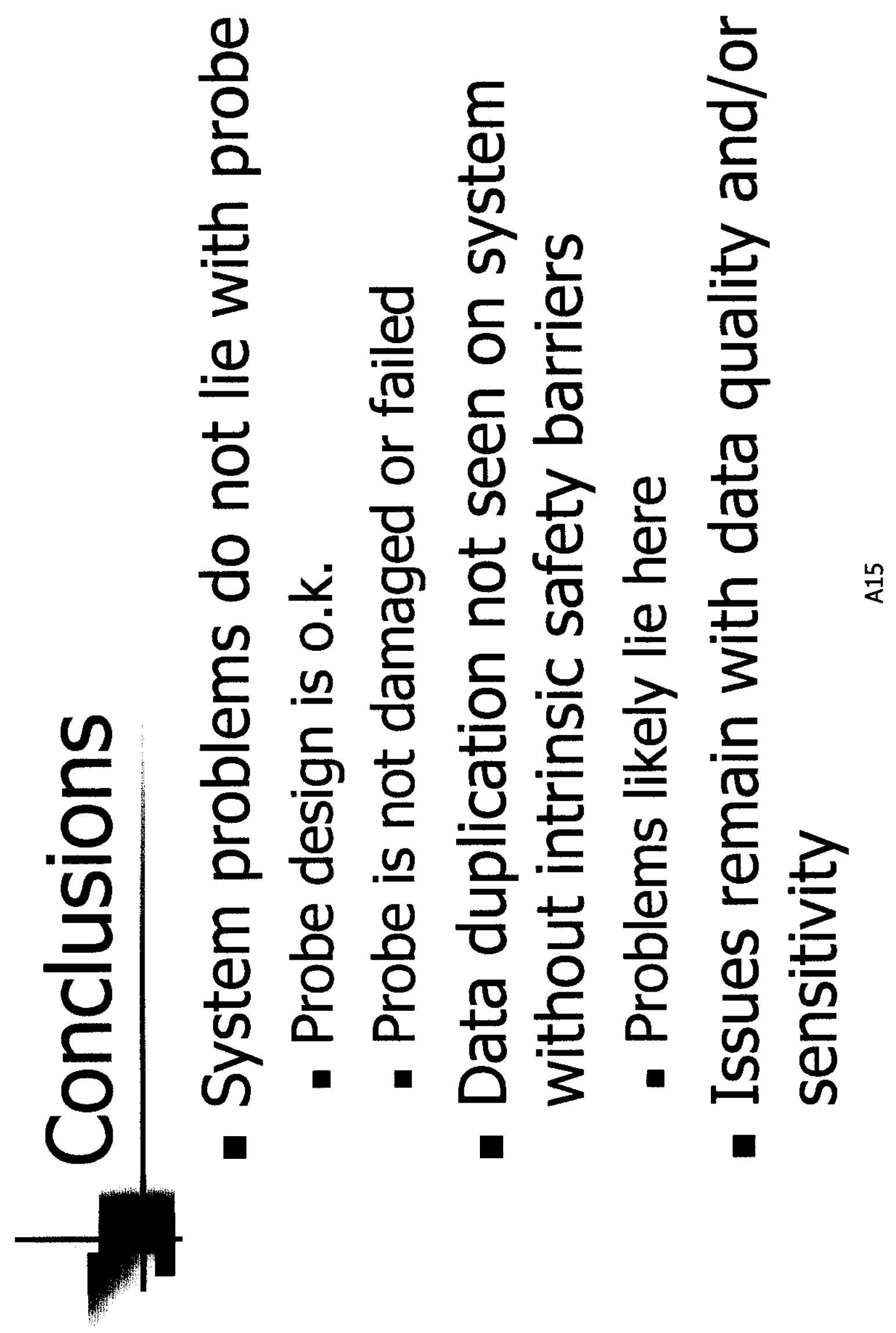




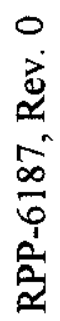

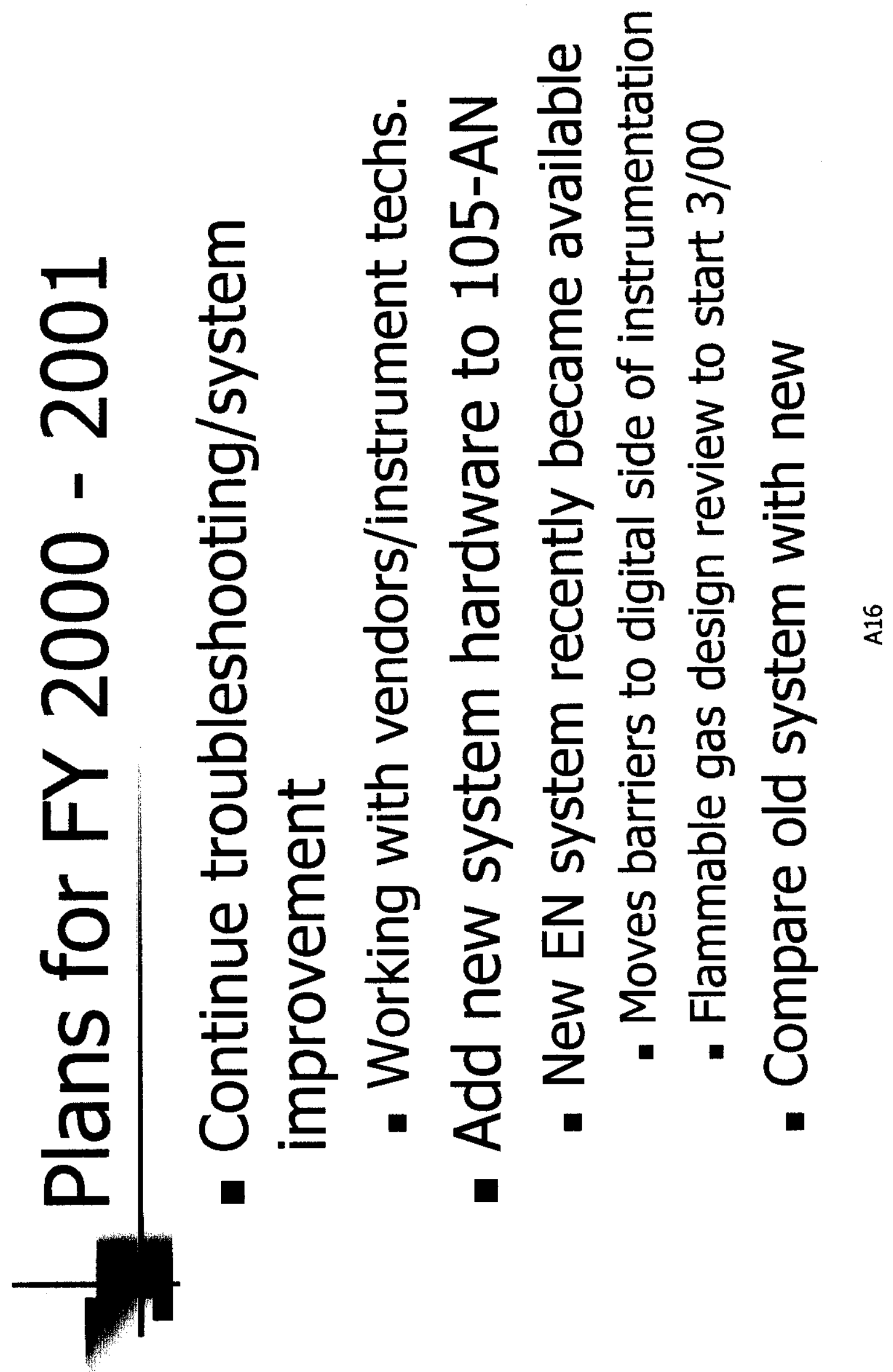




\section{Corrosion Monitoring System at ORNL}

- Adapt electrochemical noise (EN) corrosion monitoring technology developed for Hanford and SRS to 304L stainless steel radioactive waste tanks @ORNL.

- Project Team:

Tanks Focus Area - Funding Authority

Bechtel Jacobs Co. LLC - EM M\&I Contractor

Hiline Engineering - System Design \& Fabrication

Oak Ridge National Laboratory - Facilities

Waste Management Federal - System Operation

- While general corrosion @ ORNL stainless steel tanks has not been a problem, there is a benefit to understanding potential corrosion conditions, particularly at welds.

- A 50,000-gallon liquid low-level radioactive waste (LLLW) tank, W23, used primarily for storage of evaporator concentrate has been selected for corrosion monitoring system deployment.

- Tank W-23 was installed in mid-1970s in underground stainless steel lined concrete vault.

- Tank is $12^{\prime}$ in diameter by $61.5^{\prime}$ long.

- Sludges were removed from $\mathrm{W}-23$ in a 1999 tank cleaning campaign.

- LLLW in $\mathrm{W}-23$ is generally caustic, with $\mathrm{pH}$ values approximately 12.5 .

- Major anions are nitrates, nitrites, and sulfates.

- Design is scheduled for FY00, with system fabrication and deployment in FY01. 
DISTRIBUTION SHEET

\begin{tabular}{l|l}
$\begin{array}{l}\text { To } \\
\text { Distribution }\end{array}$ & $\begin{array}{l}\text { From } \\
\text { Equipment Engineering }\end{array}$ \\
\hline Project Title/Work Order & \\
FY 2000 Tanks Focus Area Corrosion Monitoring Technical Committee \\
Meeting Summary Report
\end{tabular}

\begin{tabular}{|l|l|}
\hline \multicolumn{1}{|c|}{ Name } & \\
\hline EA Fredenburg, CHG & \\
\hline EC Norman, CHG & \\
\hline GL Edgemon, Hiline & \\
\hline TP Pietrok, DOE-RL & \\
\hline MT Terry, LANL & \\
\hline BJ Williams - TFA Technical Team, PNNL & \\
\hline EJ Cruz, ORP & \\
\hline JO Honeyman, CHG & \\
\hline DJ Washenfelder, CHG & \\
\hline
\end{tabular}

\section{External:}

Kurt Gerdes, DOE office of Science and Technology, 19901 Germantown Rd, 1154

Cloverleaf Bldg., Germantown, MD 20874-1290

Office of Science and Technical Information
Page 1 of 1

Date June 27, 2000

EDT No. 629682

ECN No.

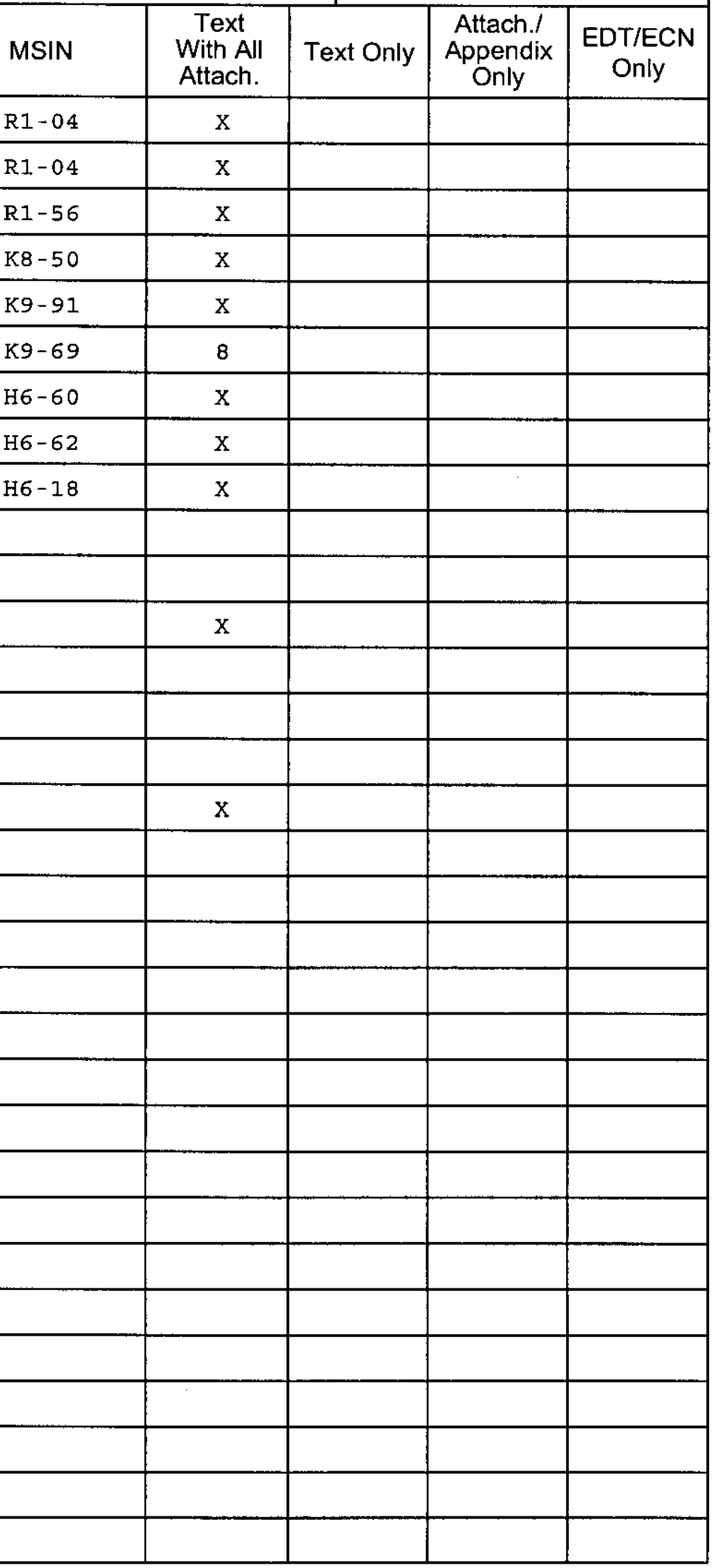

